\title{
Vitamin D deficiency in Saudi women of childbearing age with type 2 diabetes mellitus
}

\begin{abstract}
Introduction: Vitamin D deficiency is a crucial health risk element especially throughout their childbearing period. The present study aimed to examine the prevalence of vitamin D deficiency among Saudi females of childbearing age with T2DM.

Method: A cross-sectional single centre study was conducted in 1237patients with T2DM between the age 20 years to 49 years attending the Diabetes Centre at King Fahad Armed Forces Hospital, Jeddah, Saudi Arabia between January 2018 and December 2018.

Results: There were 1237 female patients between the ages 20 to 49years with T2DM with mean age was $36.6 \pm 7$.8years. Vitamin D deficiency was found in $58.4 \%$. Moreover, vitamin D deficient patients were statistically significant younger and have statistically significant higher HbA1c than non-vitamin D deficient. The mean of 25-hydroxvitamin D $(25(\mathrm{OH}) \mathrm{D})$ concentration was non-statistically significant different among and between age groups. Moreover, the frequency of vitamin D deficiency was non-statistically significant upward as age advanced with highest frequency of vitamin D deficiency was found in the fourth decade $(41.5 \%) .25(\mathrm{OH})$ $\mathrm{D}$ concentration was significantly positively correlated with age $(r=0.079, \mathrm{p}=0.004)$ and significantly negatively correlated with $\mathrm{HbA} 1 \mathrm{c}(\mathrm{r}=-0.128, \mathrm{p}=0.003)$. Regression analysis of OR of risk factors for patients with vitamin D deficiency showed that age was statistically significant associated with vitamin $\mathrm{D}$ deficiency, $(\mathrm{OR}=0.973 ; 95 \%$ $\mathrm{CI}=0.956-0.991), \mathrm{p}=0.004)$.
\end{abstract}

Conclusion: The prevalence of vitamin D deficiency in Saudi women of childbearing age with T2DM is high. We recommend larger scale studies for detecting vitamin D deficiency in our population with T2DM.

Keywords: type 2 diabetes mellitus, vitamin D deficiency, childbearing age
Volume 7 Issue 2 - 2019

\author{
Khalid S Aljabri, Samia A Bokhari \\ Department of Endocrinology, King Fahad Armed Forces \\ Hospital, Saudi Arabia
}

Correspondence: Khalid S Aljabri, Department of Endocrinology, King Fahad Armed Forces Hospital, Jeddah, Kingdom of Saudi Arabia, PO Box 9862, Jeddah 21 159, Kingdom of Saudi Arabia, Tel +96659000 8035, Fax +9662 5760 665, Email khalidsaljabri@yahoo.com

Received: March 18,2019 | Published: April 30,2019

\section{Introduction}

The emergence of high vitamin D deficiency prevalence in the last decade in particular in the Middle East justifies taking this problem seriously and planning to solve health problems associated with vitamin D deficiency. ${ }^{1-5}$

For young females, vitamin D deficiency is a crucial health risk element, especially throughout their childbearing period, when deficiency can affect the health status of both the mother and the fetus. ${ }^{6-9}$ Adequacy of vitamin D concentrations while pregnant help to ensure appropriate calcium homeostasis and bone metabolism for the mother and the fetus. ${ }^{89}$ In spite of the potentially dangerous consequences of vitamin D deficiency and even insufficiency, very few studies concerning vitamin $\mathrm{D}$ have been directed exclusively toward young women; the bulk of literature in having studied the problem of vitamin D deficiency in the general population. ${ }^{10}$

The prevalence of type 2 diabetes mellitus (T2DM) in Saudi Arabia was reported to be high, reaching up to $30 \% .{ }^{11}$ It was demonstrated that vitamin D deficiency is associated with T2DM. ${ }^{12-16}$ In addition, it was shown that diabetes mellitus prognosis may be better when the status of vitamin D deficiency is corrected and that several mechanisms have been proposed to explain these findings such as enhancement of beta cell function and reducing insulin resistance. ${ }^{17-21}$

The prevalence of vitamin D deficiency was reported to be 18 -
$84 \% .{ }^{22-25}$ In addition, vitamin D deficiency is high among the Saudi population, particularly in females with T2DM. ${ }^{26-29}$ Thus, we aimed to examine the prevalence of vitamin D deficiency among Saudi females of childbearing age with T2DM.

\section{Methods}

A cross-sectional single centre study was conducted in 1237patients with T2DM between the age 20years to 49years. Those patients attended the Diabetes Centre at King Fahad Armed Forces Hospital, Jeddah, Saudi Arabia between January 2018 and December 2018. Exclusion criteria were known hepatic or renal disease, metabolic bone disease and pregnancy. The serum concentration of $25(\mathrm{OH})$ D was measured by competitive protein binding assay using kits (Immunodiagnostic, Bensheim, Germany). Vitamin D deficiency was defined as serum 25(OH)D concentration $<50 \mathrm{nmol} / \mathrm{L} .{ }^{30}$ Glycosylated hemoglobin $(\mathrm{HbAlc})$ was measured by the high performance liquid chromatography method (Bio-Rad Laboratories, Waters, MA, USA). The total number of cohort was separated on basis of age values into three groups: 20-29years, 30-39years and 40-49years. The study was approved by the ethical committee board of King Fahad Armed Forces Hospital.

\section{Statistical analysis}

Data are presented as means \pm standard deviation (SD) or numbers (\%). Quantitative variables were compared between two groups by 
using the Student's test. Differences in categorical variables were analyzed using the chi-square test. Differences in mean serum $25(\mathrm{OH})$ D levels were tested with ANOVA (using post-hoc Tukey's honestly significant difference (HSD) tests for differences among groups). The relationship between continuous variables was assessed using coefficients of correlation. Logistic regression analysis was carried out to identify the independent predictors of vitamin D deficiency considering age and $\mathrm{HbAlc}$ as risk factors and to estimate odds ratio (OR) and $95 \%$ confidence interval (CI). P value $<0.05$ indicates significance. The statistical analysis was conducted with SPSS version 23.0 for Windows.

\section{Results}

There were 1237 female patients between the ages 20 to 49years with T2DM. The mean age was $36.6 \pm 7.8$ years (Table 1 ). The mean and median $\mathrm{HbA} 1 \mathrm{c}$ levels were $7.2 \pm 2.1$ and 6.6 respectively. The mean and median 25(OH)D concentrations were $51.3 \pm 29.2$ and $44.7 \mathrm{nmol} / 1$ respectively. Vitamin D deficiency was found in $723(58.4 \%)$ (Table 2). Moreover, vitamin D deficient patients were statistically significant younger than non-vitamin D deficient patients (36.1 $1 \pm 7.8$ vs. $37.4 \pm 7.7$ respectively, $p=0.003$ ). Vitamin $D$ deficient patients have statistically significant higher HbAlc than non-vitamin $\mathrm{D}$ deficient patients (7.4 \pm 2.2 vs. $6.9 \pm 2.0$ respectively, $\mathrm{p}=0.02)$. As expected, the mean $25(\mathrm{OH}) \mathrm{D}$ concentration was statistically significant lower in the vitamin $\mathrm{D}$ deficient patients compared to non-vitamin $\mathrm{D}$ deficient patients ( $32.8 \pm 10.3$ vs. $78.2 \pm 26.3 \mathrm{nmol} / 1$ respectively, $\mathrm{p}<0.0001)$.

Table I Patient characteristics [mean \pm standard deviation or number (\%)]

\begin{tabular}{ll}
\hline Variable & Values \\
\hline Total & 1237 \\
Age (years) & $36.6 \pm 7.8$ \\
HbAlc (\%) & $7.2 \pm 2.1$ \\
25-hydroxyvitamin D (nmol/L) & $51.7 \pm 29.2$ \\
\hline
\end{tabular}

Table 2 Vitamin D deficiency among child bearing women with Type 2 diabetes mellitus patients [mean \pm standard deviation or number (\%)]

\begin{tabular}{llll}
\hline \multirow{2}{*}{ Variable } & \multicolumn{2}{l}{ Vitamin D deficiency } & \\
& Present & Absent & P values \\
\cline { 1 - 3 } Numbers & $723(58.4)$ & $514(41.6)$ & \\
Age (years) & $36.1 \pm 7.8$ & $37.4 \pm 7.7$ & 0.003 \\
HbA1c (\%) & $7.4 \pm 2.2$ & $6.9 \pm 2.0$ & 0.02 \\
$\begin{array}{l}\text { 25-hydroxyvitamin } \\
\text { D (nmol/L) }\end{array}$ & $32.8 \pm 10.3$ & $78.2 \pm 26.3$ & $<0.0001$ \\
\hline
\end{tabular}

The mean of $25(\mathrm{OH}) \mathrm{D}$ concentration was non-statistically significant different among and between age groups (Figure 1). Moreover, the frequency of vitamin D deficiency was non-statistically significant upward as age advanced with highest frequency of vitamin $\mathrm{D}$ deficiency was found in the fourth decade $(41.5 \%)$ (Figure 2). $25(\mathrm{OH}) \mathrm{D}$ concentration was significantly positively correlated with age $(\mathrm{r}=0.079, \mathrm{p}=0.004)$ (Figure $3 \mathrm{~A})$ and significantly negatively correlated with $\mathrm{HbA1c}(\mathrm{r}=-0.128, \mathrm{p}=0.003)$ (Figure 3B). Regression analysis of OR of risk factors for patients with vitamin D deficiency showed that age was statistically significant associated with vitamin $\mathrm{D}$ deficiency, $(\mathrm{OR}=0.973$; 95\% CI=0.956-0.991), $\mathrm{p}=0.004$ ) (Table 3).

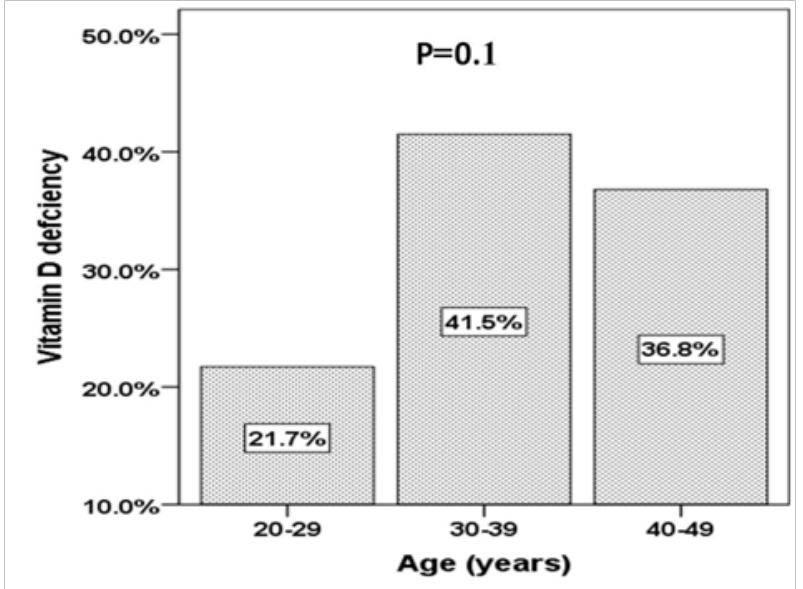

Figure I The percentage of vitamin D deficiency among child bearing women with Type 2 diabetes mellitus patients in correlation to age groups.

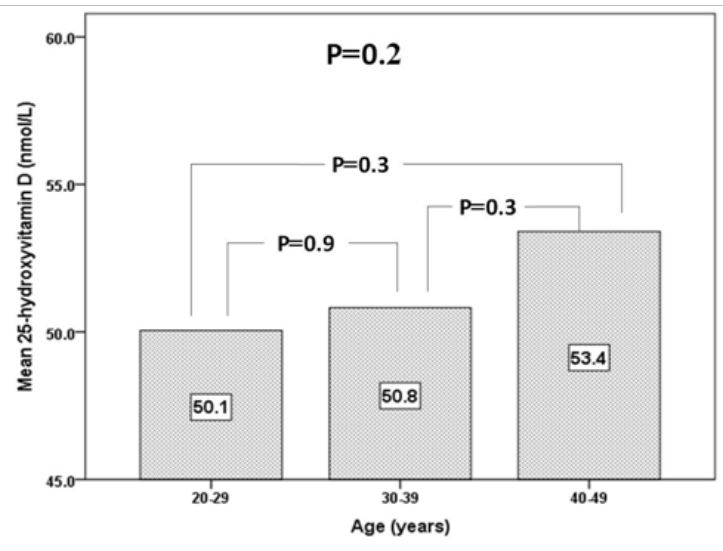

Figure 2 The 25-hydroxyvitamin D concentration in correlation to age groups.

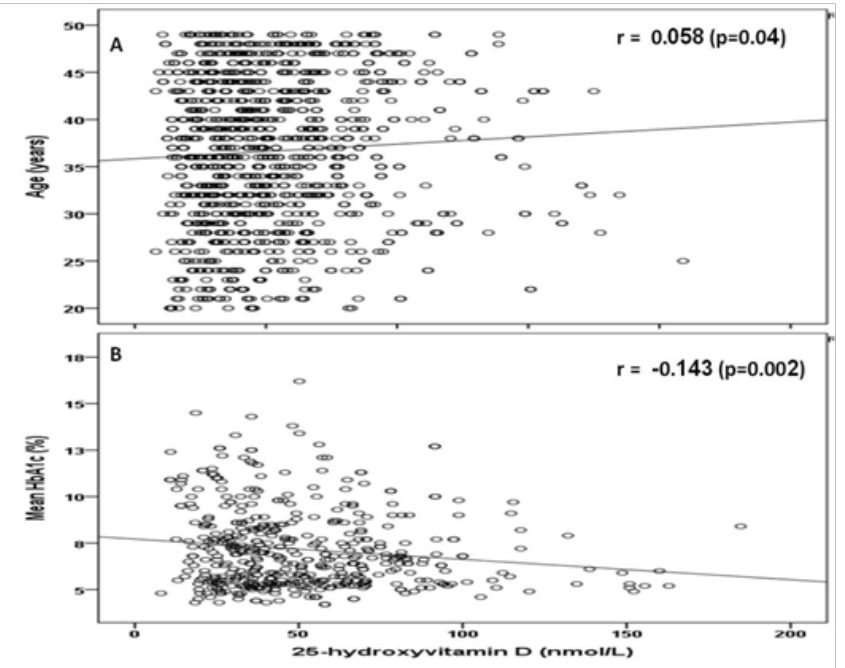

Figure 3 Correlation of 25-hydroxyvitamin $D$ concentration to age $(A)$ and HbAlc (B). 
Table 3 Regression analysis for odd ratio of risk factors for patients with vitamin $\mathrm{D}$ deficiency among child bearing women with Type 2 diabetes mellitus patients

\begin{tabular}{lll}
\hline Parameters & Odd Ratio (95\% CI) & P value \\
\hline Age (years) & $0.966(0.945-0.987)$ & 0.002 \\
HbA1c (\%) & $1.106(1.010-1.210)$ & 0.03 \\
\hline
\end{tabular}

\section{Discussion}

Vitamin D deficiency might be presented as a subclinical condition with hidden manifestations, in which the diagnosis would depend on the assessment of serum 25(OH)D levels. Serum 25(OH)D level is an indicator of vitamin D status in individuals. ${ }^{31-33}$ The present study was aimed to examine the prevalence of vitamin D deficiency among Saudi females of childbearing age with T2DM reports the vitamin D status of Saudi women of childbearing age.

We included 1234 women in this study with a median serum $25(\mathrm{OH}) \mathrm{D}$ level of $44.7 \mathrm{nmol} / \mathrm{l}$. we found the prevalence of vitamin D deficiency was $58.4 \%$. A meta-analysis found the mean $25(\mathrm{OH})$ D serum level was $32.75 \mathrm{nmol} / 1$ (95\% CI: $29.0-36.5$ and the overall vitamin D deficiency prevalence among Saudi women of childbearing years was $77.4 \% .{ }^{34}$ Similarly, low 25(OH)D levels have also been found by researchers in the United states and Middle Eastern women. ${ }^{5,26-29,35-42}$ The mean serum $25(\mathrm{OH}) \mathrm{D}$ reported among a sample of Emirati women was $21.0 \pm 15.0 \mathrm{nmol} / 1$; further, a level of $36.75 \pm 14.75 \mathrm{nmol}$ was found among Egyptian women and the highest level was found among a sample of Lebanese women with a mean of $39.5 \pm 20.5 \mathrm{nmol}^{40-42}$ The low vitamin D level may be due to several factors including avoidance of sunlight exposure. It is of importance to state that the sample size of our study is representative for patients with T2DM without comparable groups and the study population of one centre does not represent the entire city of Jeddah. We found that serum $25(\mathrm{OH}) \mathrm{D}$ was statistically significant correlated with age, that is similar to the findings of Hashemipour et $a .^{43}$ in a cohort of 1210 Iranians adult. ${ }^{43}$ The correlation of $25(\mathrm{OH}) \mathrm{D}$ to age is also in agreement with a study carried out in the United states, where vitamin $\mathrm{D}$ deficiency was found to be more common among young subjects. ${ }^{44}$ Our study showed that vitamin D deficient patients have statistically significant higher $\mathrm{HbAlc}$ than non-vitamin D deficient patients (Table 2). Moreover, 25-OHD concentration was inversely correlated with HbAlc (Figure 3B). These findings are supported by number of international studies. In contrast, some studies showed no association of low vitamin D in relation to HbA1c levels. ${ }^{45}$ But an inverse correlation between the level of vitamin D and glucose level was well known. ${ }^{46-48}$ In many studies, vitamin D levels were low in subjects having higher HbAlc values in patients with T2DM indicating that they were inversely related. ${ }^{49}$

This study has some limitations. We have based our serum $25(\mathrm{OH})$ D thresholds on prior outcome studies; no outcomes were assessed in this analysis. The data presented most likely represent the best case scenario; random sampling across all seasons should yield an even higher prevalence of vitamin D deficiency. We concluded that the prevalence of vitamin D deficiency in women of childbearing age with T2DM is high. We recommend larger scale studies for detecting vitamin D deficiency in our population with T2DM.

\section{Acknowledgments}

None.

\section{Declaration of conflicting interests}

The author(s) declared no potential conflicts of interest with respect to the research, authorship, and/or publication of this article.

\section{References}

1. Palacios C, Gonzalez L. Is vitamin D deficiency a major global public health problem? J Steroid Biochem Mol Biol. 2013;144:138-145.

2. Mitchell DM, Henao MP, Finkelstein JS, et al. Prevalence and predictors of vitamin D deficiency in healthy adults. Endocr Pract. 2012;18(6):914-923.

3. Kaddam IM, Al-Shaikh AM, Abaalkhail BA, et al. Prevalence of vitamin D deficiency and its associated factors in three regions of Saudi Arabia. Saudi Med J. 2017;38(4):381-390.

4. Hamilton B, Grantham J, Racinais S, et al. Vitamin D deficiency is endemic in Middle Eastern sportsmen. Public Health Nutr. 2010;13(10):1528-1534.

5. Basil D, Rahme M, Hoteit M, et al. Hypovitaminosis D in the Middle East and North Africa: Prevalence, risk factors, and impact on outcomes. Dermatoendocrinol. 2013;5(2):274-298.

6. Tabesh M, Garland SM, Gorelik A, et al. Improving Vitamin D Status and Related Health in Young Women: The Safe-D study-Part B. JMIR Res Protoc. 2016;5(2):e80.

7. Lapillonne A. Vitamin D deficiency during pregnancy may impair maternal and fetal outcomes. Medical Hypotheses. 2010;74(1):71-75.

8. Specker B. Vitamin D requirements during pregnancy. American Journal of Clinical Nutrition. 2004;80(6):1740S-1747S.

9. Simpson JL, Bailey LB, Pietrzik K, et al. Micronutrients and women of reproductive potential: required dietary intake and consequences of dietary deficienty or excess. Part II-vitamin D, vitamin A, iron, zinc, iodine, essential fatty acids. Journal of Maternal-Fetal and Neonatal Medicine. 2011;24(1):1-24

10. Bruyère $\mathrm{O}$, Cavalier $\mathrm{E}$, Souberbielle $\mathrm{J}$, et al. Effects of vitamin $\mathrm{D}$ in the elderly population: current status and perspectives. Arch Public Health. 2014;72(1):32.

11. Alqurashi KA, Aljabri KS, Bokhari SA. Prevalence of diabetes mellitus in a Saudi community. Ann Saudi Med. 2011;31(1):19-23.

12. Matilla C, Knekt P, Mannisto S et al. Serum 25-hydroxyvitamin D concentration and subsequent risk of type 2 diabetes. Diabetes Care. 2007;30(10):2569-2570.

13. Pittas AG, Dawson- Hughes B, Li T, et al. Vitamin D and calcium intake in relation to type 2 diabetes in women. Diabetes Care. 2006;29(3):650-656.

14. Thorand B, Zierer A, Huth C, et al. Effect of serum 25-hydroxyvitamin $\mathrm{D}$ on risk for type 2 diabetes may be partially mediated by subclinical inflammation: results from the MONICA/KORAAugsburg study. Diabetes Care. 2011;34(10):2320-2322.

15. Cigolini M, Iagulli MP, Miconi V, et al. Serum 25-hydroxyvitamin D3 concentrations and prevalence of cardiovascular disease among type 2 diabetic patients. Diabetes Care. 2006;29(3):722-724. 
16. Scragg R, Holdaway I, Singh V, et al. Serum 25-hydroxyvitamin D3 levels decreased in impaired glucose tolerance and diabetes mellitus. Diabetes Res Clin Pract. 1995;27(3):181-188.

17. Nikooyeh B, Neyestani TR, Farvid M, et al. Daily consumption of vitamin D-or vitamin D+ calcium-fortified yogurt drink improved glycemic control in patients with type 2 diabetes: a randomized clinical trial. The American Journal of Clinical Nutrition. 2011;93(4):764-771.

18. Gagnon C, Lu ZX, Magliano DJ, et al. Serum 25-hydroxyvitamin D, calcium intake, and risk of type 2 diabetes after 5 years: results from a national, population-based prospective study (the Australian Diabetes, Obesity and Lifestyle study). Diabetes Care. 2011;34(5):1133-1138.

19. Menon RK, Rickard AP, Mannan N, et al. The effects of vitamin D2 or D3 supplementation on glycaemic control and related metabolic parameters in people at risk of type 2 diabetes: protocol of a randomized, double-blind placebo-controlled trial. BMC Public Health. 2013;13(1):999.

20. de Courten B, Mousa A, Naderpoor N, et al. Vitamin D supplementation for the prevention of type 2 diabetes in overweight adults: study protocol for a randomized controlled trial. Trials. 2015;16:335-346.

21. Shab-Bidar S, Neyestani TR, Djazayery A. Vitamin D receptor Cdx-2 dependent response of central obesity to vitamin D intake in the subjects with type 2 diabetes: a randomized clinical trial. The British Journal of Nutrition. 2015;114(9):1375-1384.

22. van der Meer IM, Karamali NS, Boeke AJ, et al. High prevalence of vitamin $\mathrm{D}$ deficiency in pregnant non-Western women in The Hague, Netherlands. Am J Clin Nutr. 2006;84(2):350-353;quiz 468-359.

23. Bassir M, Laborie S, Lapillonne A, et al. Vitamin D deficiency in Iranian mothers and their neonates: a pilot study. Acta Paediatr. 2001;90(5):577-579.

24. Markestad T, Elzouki A, Legnain M, et al. Serum concentrations of vita $\neg$ min D metabolites in maternal and umbilical cord blood of Libyan and Norwegian women. Hum Nutr Clin Nutr .1984;38(1):55-62.

25. Sachan A, Gupta R, Das V, et al. High prevalence of vitamin D deficiency among pregnant women and their newborns in northern India. Am J Clin Nutr. 2005;81(5):1060-1064.

26. Serenius F, Elidrissy AT and Dandona P. Vitamin D nutrition in pregnan women at term and in newly born babies in Saudi Arabia. J Clin Pathol. 1984;37(4):444-447.

27. Taha SA, Dost SM, Sedrani SH. 25-Hydro-xyvitamin D and total calcium: extraordinarily low plasma concentrations in Saudi mothers and their neonates. Pediatr Res. 1984;18(8):739-741.

28. Ghannam NN, Hammami MM, Bakheet SM, et al. Bone mineral density of the spine and femur in healthy Saudi females: relation to vitamin D status, pregnancy, and lactation. Calcif Tissue Int. 1999;65(1):23-28.

29. Kanan RM, Al Saleh YM, Fakhoury HM, et al. Year-round vitamin D deficiency among Saudi female out-patients. Public Health Nutr. 2013;16(3):544-548.

30. Holick MF. High prevalence of vitamin D inadequacy and implications for health. Mayo Clin Proc. 2006;81(3):353-373

31. El-Hajj Fuleihan G. Vitamin D Deficiency in the Middle East and its health consequences for children and adults. Clin Rev Bone Miner Metab 2009;7(1):77-93.

32. Holick MF. Vitamin D deficiency. N Engl J Med. 2007;357(3):266-281.
33. Gordon CM, DePeter KC, Feldman HA, et al. Prevalence of vitamin D deficiency among healthy adolescents. Arch Pediatr Adolesc Med. 2004;158(6):531-537.

34. Alzaheb RA. The Prevalence of Hypovitaminosis D and Its Associated Risk Factors Among Women of Reproductive Age in Saudi Arabia: A Systematic Review and Meta-Analysis. Clinical Medicine Insights: Women's Health. 2018;(11):1-9.

35. Bodnar LM, Simhan HN, Powers RW, et al. High prevalence of vitamin D insufficiency in black and white pregnant women residing in the northern United States and their neonates. J Nutr. 2007;137(2):447-452.

36. Looker AC, Pfeiffer CM, Lacher DA, et al. Serum 25- hydroxyvitamin D status of the US population: 8-1994 compared with 2000-2004. Am J Clin Nutr. 2008;88(6):1519-1527.

37. Dawodu A, Wagner CL. Mother-child vitamin D deficiency: an international perspective. Arch Dis Child. 2007;92(9):737-740.

38. Al-Mohaimeed A, Khan NZ, Naeem Z, et al. Vitamin D status among women in Middle East. J Health Sci. 2012;2(6):49-56.

39. Hwalla N, Al Dhaheri AS, Radwan H, et al. The prevalence of micronutrient deficiencies and inadequacies in the Middle East and approaches to interventions. Nutrients. 2017;9(3):E229.

40. Al Anouti F, Thomas J, Abdel-Wareth L, et al. Vitamin D deficiency and sun avoidance among university students at Abu Dhabi, United Arab Emirates. Dermatoendocrinol. 2011;3(4):235-239.

41. El-Sagheer GM, Soliman E, Abdulla AM, et al. Vitamin D deficiency and pseudofractures in child-bearing Egyptian women: successful medical treatment helps to avoid fractures and surgical interference. Open J Endocr Metab Dis. 2016;6(8):183-191.

42. Gannage-Yared MH, Helou E, Zaraket V, et al. Serum 25 hydroxyvitamin $\mathrm{D}$ in employees of a Middle Eastern university hospital. $J$ Endocrinol Invest. 2014;37(6):541-546.

43. Hashemipour S, Larijani B, Adibi H, et al. Vitamin D deficiency and causative factors in the population of Tehran. BMC Public Health. 2004; $4: 38$.

44. Plotnikoff GA, Quigley JM. Prevalence of severe hypovitaminosis D in patients with persistent, nonspecific musculoskeletal pain. Mayo Clin Proc 2003;78(12):1463-1470.

45. Husemoen LL, Thuesen BH, Fenger M, et al. Serum $25(\mathrm{OH}) \mathrm{D}$ and Type 2 Diabetes Association in a General Population: A prospective study. Diabetes Care. 2012;35(8):1695-1700

46. Hutchinson MS, Figenshau Y, Njølstad I, et al. Serum25-hydroxyvitamin D levels are inversely associated with glycatedhaemoglobin $(\operatorname{HbA}(1 \mathrm{c}))$ The Tromsø Study. Scand J Clin Lab Invest. 2011;71(5):399-406.

47. Palomer X, Gonzalez-Clemente J, Blanco-Vaca F, et al. Role of vitamin $\mathrm{D}$ in the pathogenesis of type 2 diabetes mellitus. Diabetes Obes Metab. 2008;10(3):185-197.

48. Boucher BJ, Mannan N, Noonan K, et al. Glucose intoleranceand impairment of insulin secretion in relation to vitamin D deficiency in eastLondonAsians. Diabetologia. 1995;38(10):1239-1245.

49. Kositsawat J, Freeman VL, Gerber BS, et al. Association of A1Clevels with vitamin D status in U.S. adults: data from the National Health and Nutrition Examination Survey. Diabetes Care. 2010;33(6):1236-1238. 